\title{
Mindfulness in Everyday Life
}

\author{
Sonali Sardana* \\ Psychologist, Tech Mahindra, India
}

Submission: February 20, 2017; Published: February 23, 2017

*Corresponding author: Sonali Sardana, Psychologist, Tech Mahindra, India, Tel: +919560996249; Email: Sonali.Sardana@TechMahindra.com

\section{Opinion}

"We can make our minds so like still water that beings gather about us, that they may see, it may be, their own images, and so live for a moment with a clearer, perhaps even with a fiercer life because of our quiet"

$$
\sim \text { William Butler Yeats }
$$

The word "Mindfulness" comes from the Buddhist Philosophy which is a 2500 year-old tradition. Mindfulness means focusing on your present and observing our thoughts, feelings and bodily sensations from a distance without analyzing whether they are good or bad. It's one of the best antidotes for the stressors of modern times. In our busy world, we plan our day while listening to music, commuting to work and while doing many a random task. But in this daily hustle and bustle of our fast moving life we often find ourselves losing our connection with the present moment, on what we're doing and how we're feeling [1,2].

Practicing mindfulness not only improves mental and physical health but also involves and improves concentration and acceptance i.e., concentrating on our thoughts and sensations, and accepting those thoughts and sensation without any judgment. At times we may face situations when we may feel a bit down, may be at times upset about what someone must have said to us, or perhaps we get anxious about a meeting. In such situations we often find that our thoughts keep running and are out of control; and we may even worry a bit if we are suffering from a mental illness or pain.

Mindfulness helps in all these situations i.e., paying attention to what is happening right now, right before our eyes and ears and other senses; including the internal ones. Just as we can improve physical fitness through regular exercise, we can develop mindfulness through deliberate mental practices of Mindfulness.

Some of the techniques that can be quickly practiced wherever you are:- a) Mindfulness Meditation: Sit quietly and focus on your breathing. Allow thoughts to come and go without any judgment and return to focus on breathe and any mantra/ phrase you may want to chant.

b) Mindfulness Walking: while walking concentrate on the footsteps and then feel the ground under your feet. Keep breathing while walking. Just observe around you, staying in THE PRESENT. Let your thoughts go, just look at the sky, the view, the other people walking around, feel the wind, temperature on your skin and enjoy every moment $[3,4]$.

At times we all have noticed that in many situations, growth and insight comes from dealing with the adversity. While we may recognize these, the difference with mindfulness is that the adversities are embraced as an opportunity for growth.

Eight Hundred years ago, a Sufi Poet Rumi expressed this beautifully through the poem below

\section{The Guest House}

This being human is a guest house

Every morning a new arrival

A joy, depression, meanness

Welcome \& entertain them all!

Even if they're a crowd of sorrows,

Who violently sweep your house empty of its furniture.

Still, treat every guest honorably.

He may be clearing you out for some new delight

The dark thought, the shame, the malice

Meet them at the door laughing \& invite them in.

Be grateful for whoever comes,

Because each has been sent as a guide from beyond. 


\section{References}

1. www.helpguide.org/harvard/mindfulness.htm

2. www.blackdoginstitute.org.au/docs/10.mindfulnessineverydaylife.pdf
3. www.working-well.org/articles/pdf/mindfulness.pdf

4. www.stillmind.com.au/Documents/Everyday\%20Mindfulness.pdf

DOI: 10.19080/GJARM.2017.01.555557

\section{Your next submission with Juniper Publishers} will reach you the below assets

- Quality Editorial service

- Swift Peer Review

- Reprints availability

- E-prints Service

- Manuscript Podcast for convenient understanding

- Global attainment for your research

- Manuscript accessibility in different formats

( Pdf, E-pub, Full Text, Audio)

- Unceasing customer service

Track the below URL for one-step submission https://juniperpublishers.com/online-submission.php 